\title{
Territory Management Based On The Assessment Of Environmental Noise In Near Areas To Two Medical Centers Of Zone Planning Units 44 And 47 In Bogotá
}

Gestión del territorio basada en la evaluación del medio ambiente y ruido en áreas cercanas a dos centros médicos de Unidades de Planificación de Zona 44 Y 47 en Bogotá

Gestão do território baseada em avaliação ambiental e ruído em áreas próximas a dois centros médicos das unidades de planejamento das zonas 44 e 47 em Bogotá

\section{Baudilio Acevedo Buitrago ${ }^{1}$ Deisy Mireya Ortíz Bernal ${ }^{2}$ Estefanía Ramirez Trujillo ${ }^{3}$}

Received: September $14^{\text {th }}, 2019$ Accepted: November 26 ${ }^{\text {th }}, 2019$ Available: January $31^{\text {th }}, 2020$

How to cite this article:

B. Acevedo Buitrago, D. M. Ortíz Bernal, E. Ramirez Trujillo, "Territory Management Based on The Assessment of Environmental Noise in Near Areas to Two Medical Centers of Zone Planning Units 44 and 47 In Bogotá," Revista Ingeniería doi: https://doi.org/10.16925/2357-6014.2020.01.08

Artículo de investigación. https://doi.org/10.16925/2357-6014.2020.01.08

1 Faculty of Engineering, Universidad Libre, Bogotá, Colombia

ORCID: https://orcid.org/0000-0001-6442-5532

E-mail: baudilio.acevedob@unilibre.edu.co

2 Faculty of Engineering, Universidad Libre, Bogotá, Colombia ORCID: https://orcid.org/0000-0001-9243-2799

E-mail: deisym.ortizb@unilibrebog.edu.co

3 Faculty of Engineering, Universidad Libre, Bogotá, Colombia

ORCID: https://orcid.org/0000-0002-1451-1595

E-mail: estefania.ramirezt@unilibrebog.edu.co 


\section{Abstract}

Introduction: This article shows the evaluation of environmental noise around the medical centers located in the UPZ Americas and Kennedy Central - Bogotá, and the proposal of some actions related to the planning of the territory as a strategy for mitigation.

Problem: The Kennedy town has presented high levels of environmental noise, which is a worrying aspect due to its correlation with the effects on people's health.

Objective: This research was conducted for the purpose of compiling updated information on environmental noise in the Kennedy locality and evaluating regulatory compliance and identifing the phenomena to establish actions that lead to its mitigation.

Methodology: The measurement process was guided under the guidelines of ISO 1996:1 and the parameters established in Res. 627/2006 of the Ministry of Environment.

Results: The ambient noise levels exceed the maximum permissible limits ( $55 \mathrm{~dB}$ ) on the different days and hours of measurement. It was also determined that this phenomenon is mainly related to high vehicular flow as well as formal and informal commercial activities around medical centers.

Conclusion: There is no regulatory compliance in relation to environmental noise and the territorial plan established in the UPZ. The suggested actions are: use of parks to plant native trees that act as biological barriers, non-use of surrounding streets as secondary traffic roads and reorganization of trade activities.

Originality: Updated environmental noise data was obtained around medical centers in Kennedy and problems of inappropriate growth and development were identified.

Limitations: Lack of information on environmental noise measurements in other sectors of the area.

Keywords: Pollution, sound pressure, environmental noise, land use planning

\section{Resumen}

Introducción: Este artículo muestra la evaluación del ruido ambiental alrededor de centros médicos ubicados en la UPZ Américas y Kennedy Central - Bogotá, y la propuesta de acciones relacionadas con la planificación del territorio como estrategia de mitigación.

Problema: La localidad de Kennedy ha presentado altos niveles de ruido ambiental, lo cual es preocupante debido a sus efectos sobre la salud de las personas.

Objetivo: Esta investigación se realizó con el propósito de; recopilar información actualizada sobre el ruido ambiental en la localidad de Kennedy, evaluar el cumplimiento normativo e identificar los fenómenos para establecer acciones que conduzcan a su mitigación.

Metodología: El proceso de medición se guio bajo las pautas de ISO 1996: 1 y los parámetros establecidos en la Res. 627/2006 del ministerio de ambiente.

Resultados: Los niveles de ruido ambiental exceden los límites máximos permisibles ( $55 \mathrm{~dB})$ en los diferentes días y horas de medición, también se determinó su relación principal con el alto flujo vehicular, así como con actividades comerciales formales e informales alrededor de los centros médicos. .

Conclusión: No existe cumplimiento normativo en relación con el ruido ambiental y el plan territorial establecido en la UPZ. Las acciones sugeridas son; uso de parques para plantar árboles nativos que actúan como barreras biológicas, no uso de las calles circundantes como caminos secundarios de tráfico y reorganización de las actividades comerciales.

Originalidad: Se obtuvieron datos actualizados de ruido ambiental y se identificaron problemas de crecimiento y desarrollo inapropiados. 
Limitaciones: Falta de información de mediciones de ruido ambiental en otros sectores de la localidad.

Palabras clave: contaminación, presión acústica, ruido ambiental, planificación del uso del suelo

\section{Resumo}

Introdução: Este artigo mostra a avaliação do ruído ambiental em centros médicos localizados na UPZ Américas e Kennedy Central - Bogotá, e a proposta de ações relacionadas ao planejamento do território como estratégia de mitigação.

Problema: A cidade de Kennedy apresentou altos níveis de ruído ambiente, o que é preocupante devido aos seus efeitos na saúde das pessoas.

Objetivo: Esta investigação foi realizada com o objetivo de; reunir informações atualizadas sobre o ruído ambiental na cidade de Kennedy, avaliar a conformidade regulatória e identificar fenômenos para estabelecer ações que levem à sua mitigação.

Metodologia: O processo de medição foi orientado pelas diretrizes da ISO 1996: 1 e pelos parâmetros estabelecidos na Res. 627/2006 do Ministério do Meio Ambiente.

Resultados: os níveis de ruído ambiente excedem os limites máximos permitidos ( $55 \mathrm{~dB}$ ) nos diferentes dias e horas de medição, também foi determinada sua principal relação com o alto fluxo veicular, bem como com atividades comerciais formais e informais nos centros médicos . .

Conclusão: Não há conformidade regulamentar com relação ao ruído ambiental e ao plano territorial estabelecido na UPZ. As ações sugeridas são; uso de parques para plantar árvores nativas que atuam como barreiras biológicas, não uso de ruas vizinhas como vias secundárias de tráfego e reorganização de atividades comerciais.

Originalidade: Foram obtidos dados atualizados de ruído ambiental e identificados problemas inadequados de crescimento e desenvolvimento.

Limitações: Falta de informação sobre medições de ruído ambiental em outros setores da localidade.

Palavras-chave: poluição, pressão sonora, ruído ambiental, planejamento de uso da terra

\section{INTRODUCTION}

Noise is defined as any undesirable sound that causes a feeling of discomfort, and that can cause damage to the health of people who are exposed to it [1]. Noise pollution is one of the environmental problems that has become important worldwide and whose impact greatly affects the health of the population. People subjected to constant noise can suffer from physiological and behavioral disorders, such as sleep disturbance, concentration problems, irritability, aggressiveness, high blood pressure, even loss of hearing ability in adults, fetuses or newborns [2], [3]. These problems led the World Health Organization (WHO) to establish hearing pollution as the third most important environmental problem worldwide [4]. In people in a state of recovery, health problems become more acute, since patients are more sensitive to negative cardiovascular responses, pain management, stress levels, wound healing, and it increases the rate of exhaustion of patients, hospital workers and staff [5], [6], [7]. 
In Colombia, regulations related to environmental protection, preservation and control have been developed. The Ministry of Environment, the authority responsible for supervision and monitoring, established the national standard for the emission of noise and environmental noise and defined the permissible limits. In the city of Bogotá D.C., the latest measurement references in 2010 show that the locations with the greatest impact due to noise pollution are Kennedy, Fontibón, Chapinero and Engativá [8]. Among these, Kennedy is one of the most densely populated and is seen as a small city with major environmental problems [9], [10]. Environmental noise measurements in this location showed that 75 decibels have been reached, exceeding the maximum permissible levels, and therefore this type of pollution is considered as a high-risk factor for the health of the inhabitants of the area [11], [12], [13].

Within the Colombian environmental noise regulation Resolution 627 of 2006 of the MAVDT [14], there is a classification given by sectors, and in this way the areas adjacent to hospital centers are considered as sectors of tranquility and silence, since by their functionality, high noise levels in this type of spaces generate and induce disorders and negative impacts on the health of patients at the physiological and psychological level [15], [16]. The present investigation, documents and evaluates the regulatory compliance in points surrounding two health centers located in the UPZ Americas and Kennedy Central. It also establishes the causes and sources of noise as well as areas of influence to define actions and alternatives that can mitigate high noise levels.

\subsection{REVIEW OF LITERATURE OR RESEARCH BACKGROUND}

Previous studies have shown worrying and growing environmental problems in cities due to noise pollution and its impact on the health of the inhabitants, as well as their correlation with the use of the land. In general, it has been found that in these places there is an increase in human activities and a higher density of road traffic [17], [18], [19]. Given these facts, initiatives correlated with the dynamics of development and activities in the city have been proposed. Thus, some research carried out in different cities of different countries can be cited. In principle, in a study carried out in three different urban environments in Tripoli, Lebanon, with the aim of analyzing noise at street level, characterized by two categories: type of main activities and historical or new areas in the city, they showed results that they compared with the analysis of spatial configuration of the urban fabric, using the theory and methods of spatial syntax. The importance of sound mapping as a vital start to propose a controlled sound 
landscape of the city [20] was concluded and highlighted. In the city of Dalian, China, field studies were conducted in order to provide a reference for the improvement of quality of life in urban areas, for local governments and city planners, but in this case taking into account urban road networks and their significant influence in traffic noise [21]. The results of that study showed that when there are more lanes there is a greater demand for traffic due to connected urban land which increases the number of vehicles in groups and also in the face of a longer road segment length than allows higher vehicle speeds, a final influence of noise intensity increase is obtained. Similarly, road crossings that are classified according to the presence or absence of traffic lights, have significant direct effects on both intensity and amplitude of noise, which are likely to increase as drivers accelerate or decelerate in the middle of the segment of the road.

On the other hand, in some of the noisiest areas of the city of Cluj-Napoca, Romania, urban development trends were studied in order to increase acoustic comfort, both in residential and non-residential areas. The main innovation of that study is the approach with respect to the problem of noise, they focus on general urban planning in which the propagation and attenuation of noise was considered, with respect to the shape of the buildings and the orientation of the streets, the importance of building new parks, and building earth embankments; all this in order to reduce the impact of noise on citizens outside and inside their homes [22]. Similarly ManYuan, et al. [23], addressed in a case study in the city of Wuhan, China, the mitigation of noise pollution to ensure sustainable development in cities, mainly taking into account the characteristics of the built environment and the noise levels, as well as its association with land cover, land use and urban form. The results are significant with respect to association with the environmental factors considered, denoting that the forests and the spatial design of the buildings significantly alleviate noise levels, while the use of industrial and residential land influences the increase in noise. The control of urban density of constructed buildings is important in noise reduction.

Current studies are inclined towards urban design with green spaces conceived as essential to maintain the health and quality of life of the population and as the main axis of pollution control. Therefore, according to Rey, G. et al., when city planning, the interactions with the sociodemographic characteristics of the users and the land use, considering noise as an essential factor in the perception of these green areas must be taken into account. The results of the research carried out in the city of Cáceres, Spain, show that road traffic is the most annoying source of sound, but the degree of noise disturbance is lower because it is surrounded by a green environment than is estimated for another urban space with similar sound levels. The use of green space 
determines significant differences and relationships with sociodemographic characteristics (walking and talking activities, emotions of fear and irritability). In addition, the places in the green spaces where people frequently perform activities such as walking and relaxing have the lowest sound levels and therefore, noise is a statistically relevant factor to consider in city design [24]. Similarly, in the city of Helsinki, Finland, it was investigated how individual differences in the orientation towards the built environment versus the natural environment as well as noise sensitivity affect the psychological and physiological restoration in a built urban park, an urban forest and the center of the city. It was found that the orientation towards urban nature and to a lesser extent, the sensitivity to noise, modified the effect of the environment on the restoration and the diverse needs of the people in city planning with widely accessible green areas was concluded [25].

\section{MATERIALS AND METHODS}

The measurement methodology was based on the activities described in resolution 627 of 2006 of the Ministry of Environment, (Chapters II and III of Annex 3) and the technical requirements given in ISO 1996-1:2016 [26].

The environmental noise measurements were made, with a type 1 sound meter, model Svantek 977, with an accuracy of $+/-1 \mathrm{~dB}$ in a frequency range of $20 \mathrm{~Hz}$ to 20 $\mathrm{kHz}$, with $1 / 3$ octave time analyzer, low weighting range $A$, operated in fast mode, (with simultaneous activation for measurement also in impulsive and slow), and which was calibrated before and after each measurement with a 3M mark piston in the 114 $\mathrm{dB}$ range. Simultaneously the weather conditions (temperature, precipitation, relative humidity, wind speed and direction) were measured, with a Davis Pro weather station.

\subsection{Preliminary measurement and selection of sampling points}

In each health center, preliminary measurements were made in at least two surrounding sites in order to identify the existence of the problem and define an appropriate point where the final measurements were executed. These measurements were made for fifteen minutes since Article 5 of resolution 627 of 2006 defines that the unit time interval for an effective capture of data must be of at least fifteen minutes. In addition, weather conditions data were taken, and events that affect the measurements were identified by means of a field visit and with the help of tools such as GPS, Google 
Maps. The area $200 \mathrm{~m}$ around the measurement points was characterized recording noise emission sources.

\subsection{Definitive measurements of environment noise}

The final measurements were carried out for approximately four continuous hours at the selected critical point in each hospital, during the day, evaluating the noise levels for three days; a holiday and two days during the week. Simultaneously the meteorological conditions was recorded, a vehicle count was made manually, and events that affect the sound pressure level were noted. Preliminary and definitive measurements were made taking into account that there should be an absence of rain and dry pavement.

\section{RESULTS}

\subsection{Preliminary measurement and selection of critical points}

\subsubsection{Preliminary results in the NUEVA EPS IPS Andar Kennedy}

According to the georeferencing and characterization of the area of influence, $200 \mathrm{~m}$ around the medical center (Figure 1), it was observed that the main sources of noise are due to informal fixed and mobile commerce and also to formal commercial establishments; mainly restaurants and self-service stores. The other type of noise source is due to vehicular traffic, as the health center is located on a secondary road enabled for ambulances, cars and motorcycles as well as having several parking areas. It was also observed that there are educational centers, parks and points of high flow of people towards the registry center. In this way, two points of greatest influence were identified; both at the main entrance of the hospital, where preliminary measurements of ambient noise were made. 


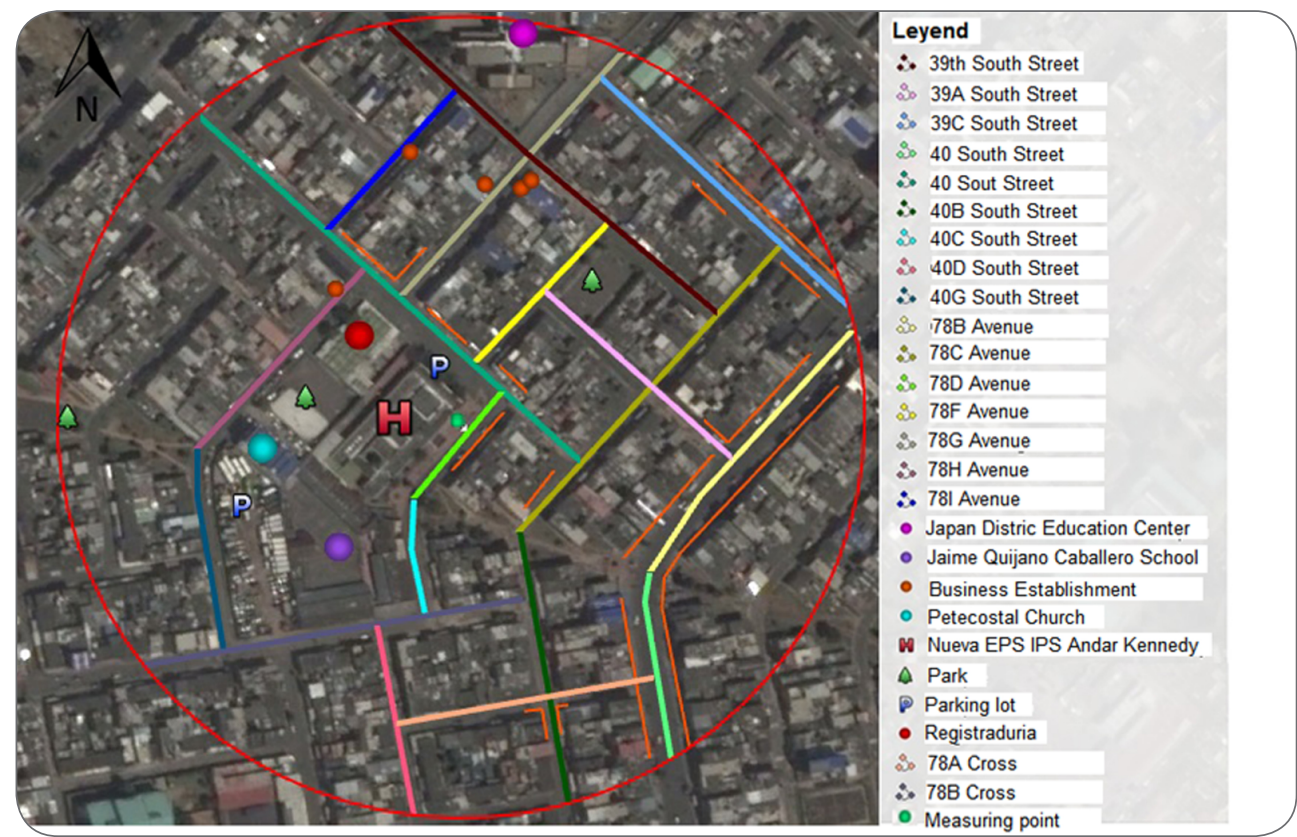

Figure 1. Nueva EPS IPS Andar Kennedy Georeferencing Source: own work

The results that were obtained in the measurements made, shown in Table 1, demonstrate that none of the selected preliminary points comply with regulatory standards regarding the sound pressure levels established for a sector of tranquility and silence (55 dB). It was also established that the main activities that affect this acoustic phenomenon are overlooked by vehicular traffic, roads and parking lots located around the health center, the passage of people talking, informal sales activities, commerce establishments, educational centers, recreation activities in the parks and noise from the passage of airplanes. Given that the highest values were found at preliminary point 1, it was selected for the final measurements.

Table 1. Results of preliminary measurements in the Nueva EPS IPS Andar Kennedy

\begin{tabular}{|c|c|c|c|c|c|c|}
\hline Site & $\begin{array}{l}\text { Distance } \\
\text { to medical } \\
\text { center }(\mathbf{m})\end{array}$ & Activities & Day / hour & $\begin{array}{l}\text { Initial } \\
\text { calibration } \\
\text { (dB) }\end{array}$ & $\begin{array}{l}\text { Final } \\
\text { calibration } \\
\text { (dB) }\end{array}$ & $\begin{array}{l}\text { SPL } \\
\text { (dB) }\end{array}$ \\
\hline $\begin{array}{l}\text { Preliminary } \\
\text { Site } 1\end{array}$ & 19,63 & $\begin{array}{l}\text { Vehicular flow, overflying } \\
\text { aircraft, pedestrian cros- } \\
\text { sing, restaurant, commer- } \\
\text { cial stalls, street sales. }\end{array}$ & $\begin{array}{l}\text { June 20, } 2018 \\
\text { / 10:00 a.m. }\end{array}$ & 114,4 & 114,4 & 72,2 \\
\hline $\begin{array}{l}\text { Preliminary } \\
\text { Site } 2\end{array}$ & 38,50 & $\begin{array}{l}\text { Vehicle flow, overflying air- } \\
\text { craft, pedestrian crossing. }\end{array}$ & $\begin{array}{l}\text { June } 20,2018 \\
\text { / 9:40 a.m. }\end{array}$ & 114,5 & 114,3 & 68,5 \\
\hline
\end{tabular}

Source: own work 


\subsubsection{Preliminary results Eusalud Traumatology and Orthopedics Clinic}

According to the georeferencing and characterization of the area of influence around the medical center (Figure 2), it was observed that the location of the hospital is on an important secondary road (78 street), and near a main road (3 avenue), so it has a high influence on ambient noise due to the constant vehicular flow. The proximity to the whereabouts of the Integrated Public Transport Service (SITP) is also evidenced, thus increasing the number of passersby around the Clinic. Additionally, it can be seen that there is a sound influence given the activity of commercial establishments near the hospital, such as restaurants and coffee shops, informal business activities. In this way, two points of greatest influence are identified and selected near the main entrance of the hospital, where preliminary environmental noise measurements were made.

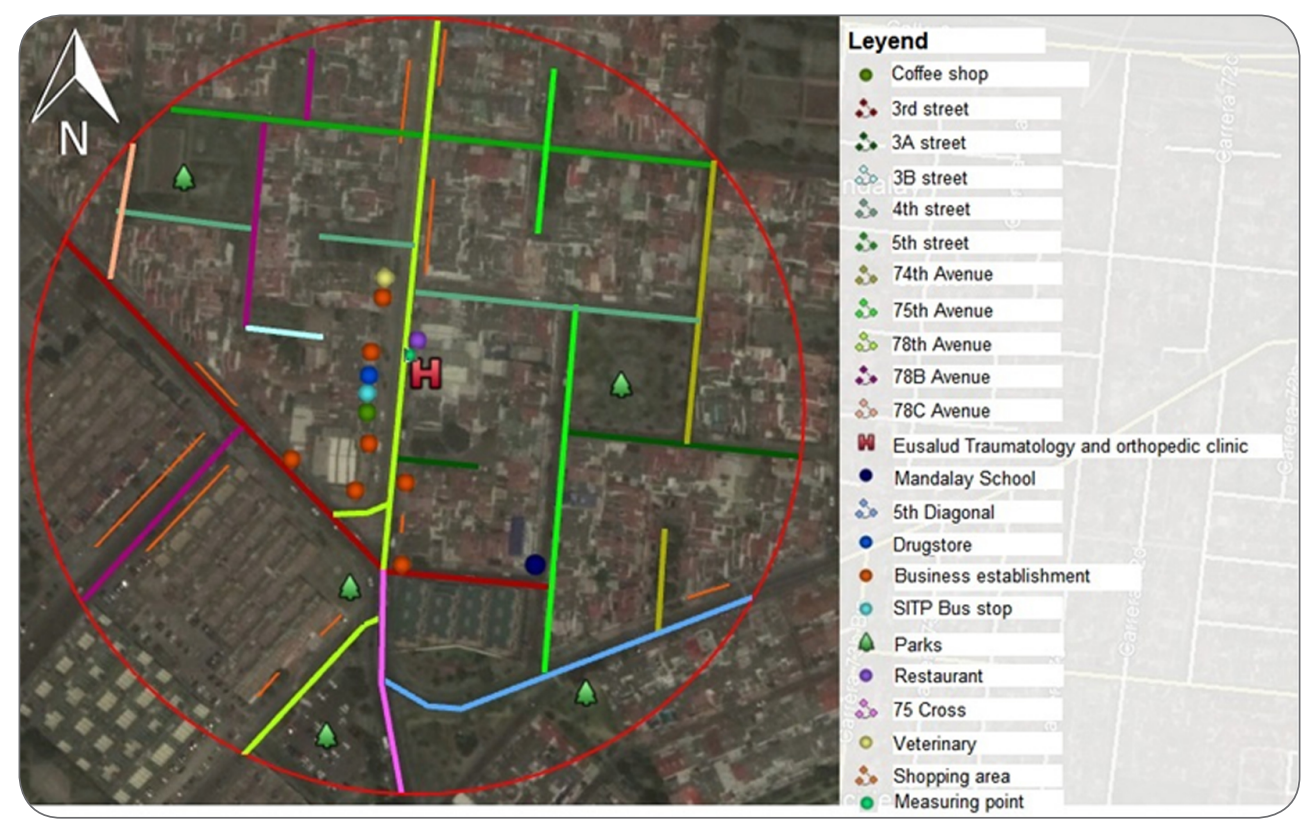

Figure 2. Eusalud Traumatology and Orthopedics Clinic Georeferencing Source: own work

The results of the preliminary environmental noise measurements (Table 2) allow us to establish that the sound pressure levels (SPL) exceed the permissible limits of the current regulations. In addition, the preliminary point 1 was chosen as the point of greatest influence to perform the final measurements, since it presents the highest value of SPL. 
Table 2. Results of preliminary measurements in Eusalud Traumatology and Orthopedics Clinic

\begin{tabular}{|c|c|c|c|c|c|c|}
\hline Site & $\begin{array}{l}\text { Distance } \\
\text { to medical } \\
\text { center }(\mathbf{m})\end{array}$ & Activities & Day / hour & $\begin{array}{l}\text { Initial } \\
\text { calibration } \\
\text { (dB) }\end{array}$ & $\begin{array}{l}\text { Final } \\
\text { calibration } \\
\text { (dB) }\end{array}$ & $\begin{array}{l}\text { SPL } \\
\text { (dB) }\end{array}$ \\
\hline $\begin{array}{l}\text { Preliminary } \\
\text { Site } 1\end{array}$ & 12,28 & $\begin{array}{l}\text { Vehicular flow, overfl- } \\
\text { ying aircraft, pedestrian } \\
\text { crossing, restaurant, } \\
\text { commercial stalls. }\end{array}$ & $\begin{array}{c}\text { June } 272018 \\
\text { 1:00 pm }\end{array}$ & 115,3 & 115,2 & 68,2 \\
\hline $\begin{array}{l}\text { Preliminary } \\
\text { Site } 2\end{array}$ & 22,79 & $\begin{array}{l}\text { Commercial establish- } \\
\text { ment, vehicular flow, } \\
\text { overflying aircraft, pedes- } \\
\text { trian crossing. }\end{array}$ & $\begin{array}{c}\text { June } 272018 \\
1: 20 \text { pm }\end{array}$ & 114,4 & 114,3 & 60,4 \\
\hline
\end{tabular}

Source: own work

\subsection{Results of definitive measurements of environmental noise}

Table 3 shows the results of the sound pressure level weighted in $\mathrm{dB}(\mathrm{A})$ corrected on average per hour for measurements made over a period of 4 hours, for the $10^{\text {th }}$ percentile and $90^{\text {th }}$ percentile values $\left(\mathrm{L}_{10}, \mathrm{~L}_{90}\right)$, and the traffic noise index $(\mathrm{TNI})$, obtained in the measurements in areas adjacent to the different medical centers under study.

Table 3. Results of SPL measurements around medical centers

\begin{tabular}{|c|c|c|c|c|c|c|c|}
\hline $\begin{array}{c}\text { MEASUREMENT } \\
\text { POINT }\end{array}$ & $\begin{array}{c}\text { MEASUREMENT } \\
\text { DAY }\end{array}$ & DATE & HOUR & $\begin{array}{l}L_{\mathrm{eq}} A \\
\text { (dB) }\end{array}$ & $\begin{array}{l}L_{10} \\
(\mathrm{~dB})\end{array}$ & $\begin{array}{l}L_{90} \\
(\mathrm{~dB})\end{array}$ & TNI \\
\hline \multirow{12}{*}{$\begin{array}{l}\text { Nueva EPS IPS } \\
\text { Andar Kennedy }\end{array}$} & \multirow{4}{*}{ Day 1 (Holiday) } & \multirow{4}{*}{$\begin{array}{l}\text { Saturday, June } 23 \\
2018\end{array}$} & $9 a m-10 a m$ & 63,7 & 66,2 & 51,3 & 80,9 \\
\hline & & & $10 a m-11 a m$ & 60,3 & 63,7 & 50,6 & 73,0 \\
\hline & & & $11 \mathrm{am}-12 \mathrm{~m}$ & 66,0 & 70,1 & 55,4 & 84,2 \\
\hline & & & $12 \mathrm{~m}-1 \mathrm{pm}$ & 67,5 & 70,6 & 55,6 & 85,6 \\
\hline & \multirow{4}{*}{ Day 2} & \multirow{4}{*}{$\begin{array}{l}\text { Tuesday June } 26 \\
2018\end{array}$} & $7 a m-8 a m$ & 68,2 & 67,9 & 55,5 & 75,1 \\
\hline & & & $8 a m-9 a m$ & 63,1 & 64,7 & 55,7 & 61,7 \\
\hline & & & $9 \mathrm{am}-10 \mathrm{am}$ & 63,1 & 65,7 & 56,2 & 64,2 \\
\hline & & & $10 \mathrm{am}-11 \mathrm{am}$ & 74,1 & 75,1 & 64,3 & 77,5 \\
\hline & \multirow{4}{*}{ Day 3} & \multirow{4}{*}{$\begin{array}{l}\text { Wednesday June } 27 \\
2018\end{array}$} & $7 a m-8 a m$ & 67,4 & 66,6 & 55,1 & 70,9 \\
\hline & & & $8 a m-9 a m$ & 63,3 & 65,2 & 55,3 & 65,1 \\
\hline & & & $9 \mathrm{am}-10 \mathrm{am}$ & 67,8 & 68,3 & 57,3 & 71,3 \\
\hline & & & $10 \mathrm{am}-11 \mathrm{am}$ & 70,6 & 67,9 & 57,8 & 68,1 \\
\hline
\end{tabular}




\begin{tabular}{|c|c|c|c|c|c|c|c|}
\hline $\begin{array}{l}\text { MEASUREMENT } \\
\text { POINT }\end{array}$ & $\begin{array}{c}\text { MEASUREMENT } \\
\text { DAY }\end{array}$ & DATE & HOUR & $\begin{array}{l}L_{\mathrm{eq}} \mathrm{A} \\
\text { (dB) }\end{array}$ & $\begin{array}{l}L_{10} \\
(\mathrm{~dB})\end{array}$ & $\begin{array}{c}L_{90} \\
(\mathrm{~dB})\end{array}$ & TNI \\
\hline \multirow{12}{*}{$\begin{array}{l}\text { Eusalud } \\
\text { Traumatología } \\
\text { y Ortopedia } \\
\text { Clinic }\end{array}$} & \multirow{4}{*}{ Day 1 (Holiday) } & \multirow{4}{*}{$\begin{array}{l}\text { Saturday, June } 23 \\
2018\end{array}$} & $1 \mathrm{pm}-2 \mathrm{pm}$ & 68,8 & 69,4 & 54,9 & 82,9 \\
\hline & & & $2 p m-3 p m$ & 67,5 & 68,6 & 57,3 & 72,5 \\
\hline & & & $3 p m-4 p m$ & 63,8 & 65,5 & 55,6 & 65,1 \\
\hline & & & $4 p m-5 p m$ & 70,7 & 67,3 & 58,4 & 64,2 \\
\hline & \multirow{4}{*}{ Day 2} & \multirow{4}{*}{$\begin{array}{l}\text { Monday, June } 25 \\
2018\end{array}$} & $2 p m-3 p m$ & 63,8 & 67,2 & 52,8 & 80,4 \\
\hline & & & $3 p m-4 p m$ & 64,8 & 68,5 & 53,2 & 84,4 \\
\hline & & & $4 p m-5 p m$ & 73,6 & 77,6 & 63,5 & 89,9 \\
\hline & & & $5 p m-6 p m$ & 70,3 & 73,6 & 50,1 & 114,1 \\
\hline & \multirow{4}{*}{ Day 3} & \multirow{4}{*}{$\begin{array}{l}\text { Tuesday, June } 26 \\
2018\end{array}$} & $3 p m-4 p m$ & 64,5 & 68,1 & 48,3 & 97,4 \\
\hline & & & $4 p m-5 p m$ & 63,8 & 68,1 & 52,4 & 85,0 \\
\hline & & & $5 p m-6 p m$ & 62,6 & 67,0 & 36,9 & 127,4 \\
\hline & & & $6 p m-7 p m$ & 62,4 & 66,1 & 51,4 & 80,1 \\
\hline
\end{tabular}

Source: own work

According to the noise measurement results obtained during the day, on the different days and periods for the two medical centers, there is no regulatory compliance as they exceed the maximum levels established in resolution 627 of the MAVDT; this being $55 \mathrm{~dB}$ for the sector $\mathrm{A}$, tranquility and silence. In addition, it was observed in situ that the same phenomenon of contribution to environmental noise are presented from the same sources that were also evidenced in the preliminary measurements, so that a similar behavior is observed.

The average measurement result represented by a higher SPL in the health center Nueva EPS IPS Andar Kennedy, was generated during the weekdays (day 2; Tuesday, June 26, 2018), at 10 a.m. at 11 am, this being $74.1 \mathrm{~dB}$. For this particular period of measurement there were several events that increased noise levels, such as the passage of street vendors, car horns and ambulance sirens (see Table 4; vehicle and event count), a phenomenon that is repeated on day 3 (Wednesday, June 27, 2018) at the same time. While for the Eusalud Traumatology and Orthopedics Clinic health center, it is presented on Monday, June 25, 2018, at 4 p.m. at 5 pm, this being 73.6 $\mathrm{dB}$. Here it was observed that at this time, the vehicular flow is increased, in addition to events such as the sound of ambulance sirens, car horns and presence of street vendors, a phenomenon that is repeated on day 1 (Saturday, June 23, 2018) at the same time. It was noted that commercial activities around health centers, constant vehicular and air traffic, people traffic, and street vendors increase on weekends. On weekdays, the highest noise levels occur in the hourly average from 5:00 pm to 6:00 pm, as the flow of vehicles and people increases. 
Table 4. Events and vehicle counting during measurements

\begin{tabular}{|c|c|}
\hline \multicolumn{2}{|c|}{$\begin{array}{l}\text { EPS ANDAR - Day } 1 \text { (Holiday) } \\
\text { Count: MOTORCYCLES : } 91 \text {, PLANES: } 18 \text {, CARS: } 488\end{array}$} \\
\hline HOUR & EVENT \\
\hline $9: 00-10: 00 \mathrm{am}$ & Alarm (2), Horn (1), Peddler (1) \\
\hline 10:00 - 11:00 am & Alarm (6), Horn (2), Peddler (1) \\
\hline $11: 00-12: 00 \mathrm{am}$ & Alarm (3), Horn (2), Peddler (2) \\
\hline $12: 00-1: 00 \mathrm{am}$ & Alarm (2), Horn (1), Peddler (3) \\
\hline \multicolumn{2}{|c|}{$\begin{array}{l}\text { EPS ANDAR - Day } 2 \\
\text { Count: MOTORCYCLES: 159, PLANES: } 37 \text {, CARS: } 518\end{array}$} \\
\hline HOUR & EVENT \\
\hline 7:00 - 8:00 am & Alarm (2) \\
\hline $8: 00$ - 9:00 am & Alarm (2) \\
\hline $9: 00$ - 10:00 am & Alarm (1), Horn (1), Peddler (2) \\
\hline 10:00 - 11:00 am & Alarm (3), Horn (2), Peddler (3) \\
\hline \multicolumn{2}{|c|}{$\begin{array}{c}\text { EPS ANDAR - Day } 3 \\
\text { Count: MOTORCYCLES: } 132 \text {, PLANES: 22, CARS: } 437\end{array}$} \\
\hline HOUR & EVENT \\
\hline $7: 00-8: 00 \mathrm{am}$ & Alarm (1), Horn (2) \\
\hline $8: 00$ - 9:00 am & Alarm (1) \\
\hline $9: 00$ - 10:00 am & Alarm (1), Peddler (2) \\
\hline 10:00 - 11:00 am & Alarm (2), Peddler (3) \\
\hline \multicolumn{2}{|c|}{$\begin{array}{l}\text { CLÍNICA EUSALUD - Day } 1 \text { (Holiday) } \\
\text { Count: MOTORCYCLES: 185, PLANES: 34,CARS: } 1072\end{array}$} \\
\hline HOUR & EVENT \\
\hline $1: 00-2: 00 \mathrm{pm}$ & Alarm (2), Horn (2), Peddler (2) \\
\hline $2: 00-3: 00 p m$ & Horn (1) \\
\hline $3: 00-4: 00 p m$ & Alarm (4), Ambulance (2) \\
\hline $4: 00-5: 00 \mathrm{pm}$ & Horn (1), Peddler (2) \\
\hline \multicolumn{2}{|c|}{ Count: MOTORCYCLES: 153, PLANES: 27, CARS: 1100} \\
\hline HOUR & EVENT \\
\hline $2: 00-3: 00 \mathrm{pm}$ & Ambulance (1) \\
\hline 3:00 - 4:00 pm & Ambulance (1) \\
\hline 4:00 - 5:00 pm & Alarm (1), Peddler (1), Ambulance (1) \\
\hline $5: 00-6: 00 \mathrm{pm}$ & Ambulance (1), Alarma (2), Horn (3) \\
\hline \multicolumn{2}{|c|}{$\begin{array}{c}\text { CLÍNICA EUSALUD -Day } 3 \\
\text { Count: MOTORCYCLES: 172, PLANES: 29,CARS: } 1126\end{array}$} \\
\hline HOUR & EVENT \\
\hline $3: 00-4: 00 p m$ & Ambulance (1), Horn (1) \\
\hline 4:00 - 5:00 pm & Alarm (1) \\
\hline $5: 00-6: 00 p m$ & Ambulance (2), Peddler (1) \\
\hline $6: 00-7: 00 \mathrm{pm}$ & Ambulance (1), Peddler (1), Horn (3) \\
\hline
\end{tabular}

In parentheses, the number of times the event is presented.

Source: own work 


\section{DISCUSSION AND CONCLUSIONS}

The location of the medical centers of study is a key factor in determining that vehicular traffic is presented as the main event of influence on environmental noise; and this is due to the proximity to main roads and secondary roads, in addition to the surrounding roads being used as alternate routes for transit. Added to this there is a growing increase in the use of motorcycles and the implementation of new routes and whereabouts of the integrated transport system that allows traffic on the main roads, but also within the neighborhood. This traffic affectation can be presented as not common for the two measurement sites, since the distance between medical centers is approximately $1.3 \mathrm{~km}$ and its environment of edifications, barriers, and main and secondary avenues is different, with the clinic Eusalud being closer to main avenuesd, and in addition they are separated by the avenue Street 26 south. Given the intensity of these traffic events that become constant, their influence on environmental noise is evidenced with the results shown in the calculation of the traffic noise index (TNI), and in the background noise denoted by the values found of $L_{90}$. It was observed that some events that were presented at the Eusalud Traumatology and Orthopedics Clinic, had to do with the passage of ambulances with the siren working because the clinic is located on a main road; (78 avenue, which joins the Americas Avenue with the 5th diagonal, leading to Boyacá Avenue).

According to the territorial planning order of Bogotá, the local planning units of study (UPZ 44 and UPZ 47) are classified as residential areas, with delimitation of trade and service. However, it is evident that there is an authorized but not ordered commercial development around these medical centers; there are drugstores, restaurants, coffee shops, parking lots and small neighborhood stores, associated in one way or another with the requirements or needs of users or employees of hospitals. There are also places not associated with medical centers, such as hardware stores, ornamentation sites, and schools. Among the unauthorized or informal trade activities, a wide variety of street sales positions were observed, located in front of the hospital areas. All this in turn increases the passage of talking people and also appreciably influences environmental noise. In this way it is evident that there is a conflict between the use of the land and the location of the hospitals under study, since according to resolution 627 of 2006 (MAVDT), the sectors where these are established must be in environments of tranquility and silence that somehow are favored in sites listed in the land use plan (POT) as a residential area. The growth of formal and informal trade was also observed, exacerbated by the growth of unemployment in the city, changing land use in the areas adjacent to the medical centers of study, leading to no regulatory compliance regarding environmental noise. 
The results of measured environmental noise during the day, in the areas surrounding the hospitals, carried out in a preliminary manner at two points around the hospital centers and the results of the definitive measurements carried out at the weekend and for two days during the week, show results above the maximum allowable limit ( $55 \mathrm{~dB}$ ), with average ranges in the measurement schedule between $63 \mathrm{~dB}$ and $74 \mathrm{~dB}$ in the Nueva EPS IPS Andar Kennedy for weekdays and $60 \mathrm{~dB}$ and $67 \mathrm{~dB}$ at the weekend. Measurement values above $60 \mathrm{~dB}$ are also present at the Eusalud Traumatology and Orthopedics Clinic health center. Average noise ranges were obtained in the measurement schedule between $62 \mathrm{~dB}$ and $74 \mathrm{~dB}$ for weekdays and $63 \mathrm{~dB}$ and $70 \mathrm{~dB}$ during the weekend demonstrating that there is no appreciable difference to values for the weekends in relation to the measured noise values during the week, since in fact the amount of the characteristic events of incidence in environmental noise do not show a decrease.

The environmental noise in the cities is a phenomenon that has begun to be found and visualized in the usual way in the cities and the correlation of this phenomenon with the means of transport is even more important, which also leads to a close relationship with air pollution from emissions of gases and particulate matter [27], [28], [29], [30], [31]. The ranges of measurement of environmental noise in which the main influence is the traffic are above $65 \mathrm{~dB}$, and it has been published by the World Health Organization (WHO) that the impacts of noise pollution at these levels generate in people; malaise, headaches, irritability, stress, and even cardiovascular effects. Within medical centers it interrupts tranquility, causes people to suffer from sleep and rest disorder, and increases blood pressure [32], [33], [34], [35].

The actions for noise management in these evaluated sectors are guided strategically and as a priority to the consideration of the problem of the location of hospital centers and regulatory compliance in relation to the sectorization given in the resolution of tranquility and silence and its non-coincidence with the POT within the UPZ of the town. In addition, since within the Colombian regulations there is no regulatory framework and guidelines or protocols for noise management, the first stage for mitigation of environmental noise has to do with the creation of government policies, with a strong correlation with the policies of transport, parking policies, etc., aimed at generating noise control and management programs that take into account technological, social, economic and political factors in the economic planning of a city with a view to creating, maintaining or rebuilding urban environments so that a good quality of life can be provided; equitable and sustainable to its inhabitants [36]. Thus, for example, the establishment of mass transportation should reduce the intensity of traffic such as the underground subway, the increase in the use of bicycles by 
providing exclusive secondary roads, technological renovation to electric cars and leverage of functionality with the creation of the necessary and adequate infrastructure. It is also important that there be compliance with authorizations or permits for construction and location of hospitals in appropriate sites, away from the main roads and designated in the POT as residential areas where green areas can be adapted, which are within the framework of green growth of the city, with native leafy trees of Bogotá type acacia negra, patula pine or moraceae rubber, in such a way that they act as living barriers against the propagation of noise and also help with the environmental control of gaseous pollutants and particulate material as well as to balance climate [37], [38].

The two medical centers of study (Nueva EPS IPS Andar Kennedy and of the Eusalud Traumatology and Orthopedics Clinic) are more specifically proposed to establish an orderly and detailed surveillance regarding the land ordering plan, in which local municipalities do not allow the authorization of commercial sites close to hospital centers and do not change the use of approved land, and design social plans for relocation and organization of trade and parking activities, stops and routes of the integrated transport system, away from the surrounding areas to the hospitals to comply with the denomination of sector of tranquility and silence, accompanied by adequate signaling as well as community awareness training [39], [40], [41], [42]. In a previous study carried out in the city of Bogotá in areas adjacent to three medical centers located in the Barrios Unidos and with the same objectives of this research [43], similar results were obtained. Regulatory noise limits were exceeded (ranges between $58 \mathrm{~dB}$ to $71 \mathrm{~dB}$ ) and with the main influence of events, related to urban traffic and the increase in formal and informal trade. There was also evidence of inadequate urban growth near the study areas and the mitigation proposals were guided towards these aspects, also evidencing that it is not a specific problem for the Kennedy locality, but that it occurs in other localities of the city. Other investigations carried out in other environments have taken into account different factors for the control of environmental noise, such as the adequacy of roads with asphalt, the prohibition of passage of heavy vehicles, which emit higher noise levels, the reduction of speed, increase in vehicle flow, decrease in noise from motorcycle leaks, construction of buildings that act as a barrier and architectural designs of city construction that take into account the wind direction for propagation and dispersion of pollutants [44], [45]. Despite this, some of these actions are not yet adaptable and would not fulfill their purpose in the study locations and, in general in the city of Bogotá, since the main roads are not wide enough to allow for better vehicle flow and speed reduction, it generates traffic jams that, due to braking and acceleration phenomena, in addition to the poor state of maintenance 
of the tracks, noise emissions are increased. In this way it is necessary to further investigate measurement studies that allow for the construction of environments in the city where care is taken of exposure to inadequate noise levels.

The measurements made in the areas surrounding the medical centers, Eusalud Traumatology and Orthopedics Clinic and Nueva EPS IPS Andar Kennedy, help to conclude that:

- There is no regulatory compliance with respect to the maximum permissible levels of environment noise established by MAVDT Resolution 627 of 2006 (55 dB).

- The inadequate and unordered growth of informal and formal authorized activities and vehicular traffic generate a problem of air quality related to noise around hospital areas established as sectors of tranquility and silence.

- There is no correlation between the POT and the denomination of sectors of tranquility and silence in the study areas due to; the proliferation of authorized commercial activities, the inadequate location of the two medical centers, the authorization by the district administration of SITP whereabouts in surrounding areas, some appropriation of land adjacent to medical centers.

- Population growth and urban development in UPZ 44 and 47 of the Kennedy town, Bogotá, has not been taken into account or associated with the problem of environmental noise pollution.

- The suggested actions to be carried out in each area near the hospitals are; use of parks to plant native trees that act as biological barriers, the non-use of the surrounding streets as secondary traffic roads and the reorganization of formal and informal trade.

\section{REFERENCES}

[1] E. Murphy, E. King and H. Rice, "Estimating human exposure to transport noise in central Dublin, Ireland," Environment International, vol. 35, no. 2, pp. 298-302, 2009. doi: https://doi. org/10.1016/j.envint.2008.07.026

[2] T. Donath, "Effects of environmental noises and sounds on the quality of life controlled by the central nervous system," Orvosi hetilap, vol. 147, no. 16, pp. 737-739, 2006. Available: https:// europepmc.org/abstract/med/16711259 
[3] Committee on environmental Health, "Noise: a hazard for the fetus and newborn," Pediatrics, vol. 100, no.4, pp. 724-727, 1997. [Online]. doi: https://doi.org/10.1542/peds.100.4.724

[4] D. Schwela, "World Health Organization Guidelines on Community Noise," Presentation at the TBR session, vol. 391, 2001. [Online]. doi: https://doi.org/10.3397/1.2839659

[5] H. Morrison, H. Shaffner, E. Garret, J. Fakler, "Noise: stress, and annoyance in a pediatric intensive care unit," Critical care medicine, vol. 31, no. 1, pp. 113-119, 2003. [Online]. doi: https:// doi.org/10.1097/00003246-200301000-00018

[6] J. Norbeck, "Perceived job stress, job satisfaction, and psychological symptoms in critical care nursing," Research in Nursing \& Health, vol. 8, no. 3, pp. 253-259, 1985. [Online]. doi: https://doi.org/10.1002/nur.4770080307

[7] M. Stanchina, M. Abu-Higle, B. Chaudhry, C. Carlisle, R. Millman, "The influence of white noise on sleep in subjects exposed to ICU noise," Sleep Medicine, vol. 6, no. 5, pp. 423-428, 2005. [Online]. doi: https://doi.org/10.1016/j.sleep.2004.12.004

[8] J. Pacheco, J. Franco, E. Behrentz, "Caracterización de los niveles de contaminación auditiva en Bogotá: Estudio piloto," Revista de Ingeniería, no. 30, pp. 72-79, 2009. [Online]. Available: http://www.scielo.org.co/pdf/ring/n30/n30a10.pdf

[9] Alcaldía Mayor de Bogotá (2012, junio 10). Observatorio ambiental. [Online]. Available: http://oab.ambientebogota.gov.co/es/con-la-comunidad/noticias/kennedy-es-la-zona-mas -ruidosa-de-bogota.

[10] Alcaldía Local de Kennedy (2017). Alcaldía Mayor de Bogotá. Obtenido de Secretaría Distrital de Ambiente. [Online]. Available: https://oab.ambientebogota.gov.co/apc-aa-files/a65cd60a57804f3f1d35afb36cfcf958/palkennedy2017a2020_1.pdf

[11] G. Loupa, A. Katikaridis, D. Karali, S. Rapsomanikis, "Mapping the noise in a Greek general hospital," Science of The Total Environment, vol. 646, pp. 923 - 929, 2019. [Online]. doi: https:// doi.org/10.1016/j.scitotenv.2018.07.315

[12] K. Stassen, P. Collier, R. Torfs, "Environmental burden of disease due to transportation noise in Flanders (Belgium)," Transportation Research Part D: Transport and Environment, vol. 13, no. 6, pp. 355 - 358, 2008. [Online]. doi: https://doi.org/10.1016/j.trd.2008.04.003

[13] G. Acevedo. (2017, noviembre). Aumenta el ruido en los hospitales. Mundo HVA\&R. [Online]. Available: https://www.mundohvacr.com.mx/2011/11/aumenta-el-ruido-en-los-hospitales/ 
[14] Ministerio de ambiente, vivienday desarrollo territorial, Resolución 0627 de 2006, Norma nacional de emisión de ruido y ruido ambiental, 2006. [Online]. Available: http://www.minambiente. gov.co/images/AsuntosambientalesySectorialyUrbana/pdf/emisiones_atmosfericas_contaminantes/norma_ruido/Resolucion_627_de_2006_-_Norma_nacional_de_emision_de_ ruido.pdf

[15] E. Lasky, "Noise and light exposures for extremely low birth wight newborns during their stay in the neonatal intensive care unit," Pediatrics, vol. 123, no. 2, pp. 540, 2009. [Online]. doi: https://doi.org/10.1542/peds.2007-3418

[16] F. Gutiérrez, "Estudio general de la contaminación acústica en las ciudades de Andalucía," Cuadernos geográficos de la Universidad de Granada, vol. 49, no 2, pp. 55 - 94, 2011. [Online]. Available: https://www.redalyc.org/pdf/171/17122051003.pdf

[17] M. Annerstedt, P. Östergren, J. Björk, P. Grahn, E. Skärbäck, P. Währborg, "Green qualities in the neighbourhood and mental health - Results from a longitudinal cohort study in Southern Sweden," BMC Public Health, vol. 12., pp. 337, 2012. [Online]. doi: https://doi. org/10.1186/1471-2458-12-337

[18] W. Babisch. "The noise/stress concept, risk assessment and research needs," Noise and health, vol. 16, no. 4, pp 1-11, 2002. [Online]. Available:

http://www.noiseandhealth.org/article.asp?issn=1463-1741;year=2002; volume=4;issue=16;spage=1;epage=11;aulast=Babisch

[19] C. Hu, T. Tkebuchava, "E-Noise: An increseasinggly relevant health risk," Journal of Integrative Medicine, vol. 17, pp 311-314, 2019. [Online]. doi: https://doi.org/10.1016/j.joim.2019.07.003

[20] N. Mohareb, S. Maassarani, "Assessment of street-level noise in three different urban settings in Tripoli,” Urban Climate, vol. 29, 2019. Article 100481. [Online]. doi: https://doi.org/10.1016/j. uclim.2019.100481

[21] L. Xiaodong, K. Jian, Z. Peisheng, C. Jun, G. Ca, Z. Yuan, "Influence of urban road characteristics on traffic noise," Transportation Research Part D: Transport and Environment, vol. 75, pp 136-155, 2019. [Online]. doi: https://doi.org/10.1016/j.trd.2019.08.026

[22] V. Marusceac M. Ciotlaus, "Optimizing urban landscapes in regard to noise pollution," Procedia Manufacturing, vol. 32, pp. 161-166, 2019. [Online]. doi: https://doi.org/10.1016/j. promfg.2019.02.197 
[23] Y. Man, Y. Chaohui, S. Yi, C. Weiqiang, "Examining the associations between urban built environment and noise pollution in high-density high-rise urban areas: A case study in Wuhan," China Sustainable Cities and Society, vol. 50, 2019, Article 101678. [Online]. doi: https://doi. org/10.1016/j.scs.2019.101678

[24] G. Rey, J. Barrigón, D. Montes, P. Atanasio, "Relationships among satisfaction, noise perception, and use of urban green spaces," Science of The Total Environment, vol. 624, pp. 438-450, 2018. [Online]. doi: https://doi.org/10.1016/j.scitotenv.2017.12.148

[25] A. Ojala, K. Korpela, L. Tyrväinen, P. Tiittanen, T. Lanki, "Restorative effects of urban green environments and the role of urban-nature orientedness and noise sensitivity: A field experiment," Health \& Place, vol. 55, pp. 59-70, 2019. [Online]. doi:: https://doi.org/10.1016/j. healthplace.2018.11.004

[26] ISO 1996-1:2016, Acoustic - Description, measurement and assessment of environmental noise - part 1 Basic quantities and assessment procedures. [Online]. Available: https://www.iso.org/ standard/59765.html

[27] D. Carlos, "A different route to health: implications of transport policies," Br Med J; vol. 9, pp. 1686-1689, 1999. [Online]. doi: https://doi.org/10.1136/bmj.318.7199.1686

[28] S. Stansfeld, M. Matheson, "Noise pollution: non-auditory effects on health," Br Med Bull, vol. 68, pp. 243-257, 2003. [Online]. doi: https://doi.org/10.1093/bmb/ldg033

[29] A. McMichael, "The urban environment and health in a world of increasing globalization: issues for developing countries," Bulletin of the World Health Organization, vol. 78, no. 9, pp. 11171126, 2000. [Online]. Available: https://www.ncbi.nlm.nih.gov/pmc/articles/PMC2560839/

[30] A. McMichael, "Health at the crossroads: transport policy and urban health," London School of Hygiene and tropical medicine fitth annual public health forum "Transport and health: assessing the risks", pp. 9-26, 1997.

[31] P. Connolly, "Mexico City: our common future?," Environment and Urbanization, vol. 11, no. 1, pp. 53-78, 1999. [Online]. doi: https://doi.org/10.1177/095624789901100116

[32] Organización Mundial de la Salud (2015, febrero 27). La OMS pone de relieve la grave amenaza de la exposición al ruido recreativo. [Online]. Available: https://www.who.int/mediacentre/ news/releases/2015/ear-care/es/ 
[33] Organización Mundial de la Salud, Guías para el ruido urbano. Ginebra: Universidad de Estocolmo, pp. 20, 1995. [Online]. Available: https://ocw.unican.es/pluginfile.php/965/course/section/1090/Guias\%2520para\%2520el\%2520ruido\%2520urbano.pdf

[34] C. Londoño, A. Echeverri, "Diseño de la red de vigilancia de ruido para los municipios que conforman el Área Metropolitana del Valle de Aburrá," Revista Ingenierías Universidad de Medellín, vol. 8, no. 14, pp. 21-38, 2009. [Online]. Available: https://ocw.unican.es/pluginfile. php/965/course/section/1090/Guias\%2520para\%2520el\%2520ruido\%2520urbano.pdf

[35] E. Ohrstrom, E. Hadzibajramovic, M. Holmes, et al. "Effects of road traffic noise on sleep: studies on children and adults," Journal of Environmental Psychology, vol. 26, no. pp. 116 -216. 2006. [Online]. doi: https://doi.org/10.1016/j.jenvp.2006.06.004

[36] J. Wu, “Urban vegetation and air pollution," Int. Soc. Expo. Sci. Newsl., vol. 5, pp. 1-18, 2018.

[37] B. Givoni, "Impact of planted areas on urban environmental-quality," Atmos. Environ., vol. 25, no. 3, pp. 289-299, 1991. [Online]. doi: https://doi.org/10.1016/0957-1272(91)90001-U

[38] J. Gallagher, Revolution Detroit: Strategies for urban reinvention. Detroit: Wayne State University Press, 2013.

[39] D. Michaud, et al., "Noise annoyance in Canada", Noise and Health, vol. 7, no. 27, pp. 39, 2005. [Online]. doi: https://doi.org/10.4103/1463-1741.31634

[40] V. Escobar, C. Gómez, J. Pérez, "An objective method of street classification for noise studies," Applied Acoustics, vol. 141, pp. 162-168, 2018. [Online]. doi: https://doi.org/10.1016/j. apacoust.2018.07.003

[41] A. Can, M. Rademaker, T. Van Renterghem, V. Mishra, M. Van Poppel, A. Touhafi, A., et al., "Correlation analysis of noise and ultrafine particle counts in a street canyon," Science of the Total Environment, vol. 409, no. 3, pp. 564-572, 2011. [Online]. doi: https://doi.org/10.1016/j. scitotenv.2010.10.037

[42] Council of the European Union, European Parliament, "Relating to the assessment and management of environmental noise - Declaration by the Commission in the Conciliation Committee on the Directive relating to the assessment and management of environmental noise," Directive 2002/49/EC of the European Parliament and of the Council, 2002.

[43] L. Chaux, B. Acevedo, "Evaluación de ruido ambiental en alrededores a centros médicos de la localidad barrios unidos, Bogotá," Revista científica, vol 2, no. 35, pp. 234-246. [Online]. doi: https://doi.org/10.14483/23448350.13983 
[44] R. Khaiwal, T. Singh, et al., "Assessment of noise pollution in and around a sensitive zone in North India and its non-auditory impacts," Science of the Total Environment, vol. 566, pp. 981987, 2016. [Online]. doi: https://doi.org/10.1016/j.scitotenv.2016.05.070

[45] J. Bohatkiewicz, "Noise control plans in cities - selected issues and necessary changes in approach to measures and methods of protection," Transportation Research Procedia, vol. 14, pp. 2744-2753, 2016. [Online]. doi: https://doi.org/10.1016/j.trpro.2016.05.458 